\title{
The Role of the Perceived Benefits on the Relationship between Service Quality and Customer Satisfaction: A Study on the Islamic Microfinance and SMEs in Yemen Using PLS Approach
}

\author{
Fahmi Shaaban Fararah ${ }^{1} \&$ Abdullah Kaid Al-Swidi ${ }^{2}$ \\ ${ }^{1}$ Seiyun Community College, Hadramout, Yemen and Kulliyyah Muamalat, Insaniah University College, Alor \\ Setar, Kedah Darul Aman, Malaysia \\ ${ }^{2}$ Othman Yeop Abdullah Graduate School of Business,University Utara Malaysia, Sintok, Malaysia \\ Correspondence: Abdullah Kaid Al-Swidi, Othman Yeop Abdullah Graduate School of Business,University \\ Utara Malaysia, Sintok, Malaysia. Tel: 60-12-466-2754. E-mail: swidi@uum.edu.my
}

\author{
Received: March 10, 2013 Accepted: May 26, 2013 Online Published: August 1, 2013 \\ doi:10.5539/ass.v9n10p18 URL: http://dx.doi.org/10.5539/ass.v9n10p18
}

The Authors would like to acknowledge that this study has been partially financed by the Students' Sponsorship Charitable Organization in Al-Mukalla, Hadhramout, Yemen represented by Mr. Fatehi Abdullah Basabaih to whom they want to extend the gratitude and appreciation.

\begin{abstract}
This study aims to examine the effect of Service Quality on the satisfaction of the SMEs owners on the Islamic Microfinance Products. Due to the increasing importance of Islamic banking and financing system, the concern is to what extent this system can satisfy the consumers and contributes to the overall economic development. The model of this study was developed to examine the effectiveness of Islamic banking and financing system. To test the hypothesized model, the data were collected from the SMEs owners in Yemen through a self-administered questionnaire. Out of 250 distributed questionnaires, 151 were returned and were used for data analysis. The results of this study shown the significant effect of Service Quality on the SMEs owners' satisfaction and the perceived benefits obtained through their dealing with Islamic Microfinance system. In addition, the results of this study confirmed that the perceived benefit partially mediates the relationship between Service Quality and SMEs owners' satisfaction. However, the moderating effect of perceived benefits on the relationship between service quality and satisfaction was not confirmed.
\end{abstract}

Keywords: Islamic banking and finance system, Islamic micro-finance system, service quality, customer satisfaction, partial least squares, SMEs/Yemen

\section{Introduction}

The main principal of Islamic banking and finance system is to support the poor through the microfinance system (Rahman, 2007). The Islamic finance industry has an annual growth between $10 \%$ to $15 \%$ percent and becoming more competitive with traditional financing sectors (Othman \& Owen, 2001). In the current challenging environment, all financial institutions have to give a great attention to the customer satisfaction on their services or products. In fact, customers are the most important factor for them to achieve the success (Hennig, Thurau \& Klee, 1997). However, if the customers are satisfied, they are more likely to be loyal to services provider (Deng et al., 2009). The main aim of any organization is to satisfy the customers' needs and meet their expectations to sustain their business (Turel \& Serenko, 2006).

Moreover, most of previous research focused on the customer satisfaction in the banking sector for both Islamic banks and conventional banks in different countries by applying SERVQUAL or CARTER (compliance, Assurance, reliability, tangible, empathy, responsiveness) models to measure the service quality of Islamic and conventional banks. For instance some researches such as Shafie, Azmi, and Haron, (2004); Ramdhani, Ramdhani, \& Kurniati, (2011); and Othman \& Owen (2001) focused on examining the service quality of Islamic banks, more specifically these studies tried to investigate customer satisfaction by using CARTER model. However, there is a lack of studies to examine the satisfaction of customers on services provided by Islamic 
microfinance institutions. More importantly, in Yemen there is a lack of studies examining the effectiveness of Islamic microfinance system and to what extent the customers are satisfied, by using the factors that mentioned in this study.

It has been widely noticed that the poverty rate is dramatically rising in the Islamic world, in general, and in Yemen in particular. According to Yemen Country Profile, (2008) there are 45\% of Yemeni population lower than the poverty line. However, it has been globally recognized that the major responsibility of Islamic banking and finance system is to contribute to the economic development through supporting the SME sector run by the poor (Rahman, 2007).

One of the main obstacles to SMEs' growth and survival in Yemen, and in other developing countries, is the difficulty to access the financial resources. Jalilian and Kirkpatrick (2001) reported that a $10 \%$ increase in financial services may increase the income rate of poor people by $4 \%$. SMEs in Yemen constitute about $99.6 \%$ of all business organizations, employing more than 485,000 workers and contribute to a more than $7.2 \%$ in the Gross Domestic Product (GDP). A survey conducted by the Ministry of Planning and International Cooperation in 2004 showed that less than $12.2 \%$ of Yemeni SMEs have an access to the required financial resources. To enhance the development of the Yemeni Economy, reduce the poverty, and to reduce the unemployment rate, SMEs sector proved its ability to be an efficient solution (Al-Swidi \& Mahmood, 2011; Ministry of Planning and International Cooperation MOPIC, 2004).

According to CGAP (2011a), it is reported that $72 \%$ of the people living in Muslim-majority countries (i.e., Yemen) do not use formal financial services. In addition, CGAP (2012f) reported that the traditional microfinance institutions in Arabic world have more than thousands of active borrowers, while Islamic Microfinance institutions have lower than 10000 borrowers, and in some cases they reach to only 2000 or 3000 active borrowers. Therefore, Islamic microfinance is still lagging behind in targeting customers in comparison to the traditional microfinance system. The poor performance of Islamic microfinance system in the developing countries, in general, and in Yemen, in particular can be attributed mainly or partly to the low service quality, more specifically, the quality of services provided by Islamic microfinance is not as that of the conventional microfinance system. This is due to the experience of the conventional system. This can be deemed right since in the majority-Muslims countries even though the people are very much concerned whether their transactions are Sharia compliant, they are intensively dealing with traditional microfinance system, in general, has been practicing the financial transactions not very much different from the conventional system. Therefore, the benefits perceived by dealing with Islamic microfinance system are not highly differentiated from dealing with the conventional microfinance system.

In Yemen, the most critical issue regarding the performance of Islamic microfinance system is the low outreach to the SMEs. Specifically, the Islamic microfinance system is currently dealing with only $11 \%$ of the SMEs being run in the country. This percentage is considered very low in a country with $99 \%$ Muslims. To achieve the effectiveness, Islamic microfinance system should enhance its ability to reach the customers and contribute to the economic development of the country through supporting SMEs.

Furthermore, Service Quality is one of the main determinants of customer satisfaction in Islamic banking and finance industry for many reasons. First, there is a lack of knowledge and research on management in general and service quality in particular in this industry. Second, the annual growth between $10 \%$ and $15 \%$ calls for more attention to examine the level of the quality of services provided to the customers. Third, there has been an intensive competition between conventional and Islamic banking and finance systems and this requires that the service quality should be always monitored and improved (Othman \& Owen, 2001).

\section{Small and Medium Sized Enterprises in Yemen}

According to Al-Swidi and Mahmood (2011), Yemen is one of the least developing countries in the region with around $42 \%$ of the population live under the poverty line with an average of USD 45 per. In addition, Yemen ranked as 149 out of 171 in terms of Human Resource Development and has an increasing unemployment rate that reached $35 \%$ by 2008 . More importantly, SMEs play a significant role in the economy in all countries by providing job opportunities and act as suppliers for large organizations. Based on the survey of the year 2000, the SMEs in Yemen is considered to be one of solutions for many economic problems such as the increasing unemployment rate and poverty (MOPIC, 2004).

Ministry of Planning and International Cooperation Yemen (MOPIC), (2004) reported that the definition of SMEs is a big problem to face the researchers in this sector, the differences between the large sector and SMEs is not only in the number of workers but there are another factor such as capital and technology. The famous definition of SMEs in Yemen adopted in many researches is that according to (MOPIC) government of Yemen 
defined SMEs as from 1- 4 employees are small businesses, the medium from 5-9 workers, and the large firm are from 10 - above employees.

According to Al-Kuhali (2011) around 27\% of all SMEs in Yemen established in Sana'a, 10.5\% in Taiz and 7.8\% in Ibb, this relevant to the increase of personal income in these governorates, and there are many of Yemen population living in these cities. Malhotra et al. (2006) show that as a team of World Bank the World Bank defined SMEs depending on a number of employees the microenterprise from 1-10 employees, and small enterprise from 11-50 workers, and the medium enterprise from 51- 300 employees. The World Bank definition of the SMEs is not the same as the Yemeni definition. Based on Bo (2010) SMEs are "usually medium or small-scale enterprises with simple internal organization structure, independent production and operation, non-monopoly of relevant product markets, corresponding social responsibility, and different kinds of ownerships and organization patterns".

\section{Issues Related to the SMEs Development in Yemen}

According to National Information System (2012) there are many problems and obstacles facing SMEs sector in Yemen. Some of these problems listed in the following:

1) Limited capacity for business owners and small enterprises in obtaining funding sources they need in their industry.

2) Technical problems and the scarcity of trained and technical manpower.

3) Administrative problems, regulatory and marketing.

4) The inability to access the information for the purpose of investment and technologies used in this area.

5) The problem of the complexity of laws and legislation on the establishment of projects.

6) The inability of the local SMEs to compete in foreign markets.

7) Breadth of the phenomena of smuggling and dumping.

8) A lack of a clear strategy for industrial development.

9) Lack of adequate industrial infrastructure.

10) Lack of attention to sectors that represent a fundamental building block for the development of the industrial sector such as agriculture, fisheries and mining and Lack of interest in research centers and industrial development.

11) The increase of inflation, taxes, and high prices of input, increase of rent, high price of public services, limit of equipment and decline of revenue (MOPIC, 2004)

\section{Customer Satisfaction}

Bhattacherjee (2001) defined the customer satisfaction as the positive feeling (satisfaction) developed by the customers towards specific products and service. Moreover, customer satisfaction is defined as the evaluation of the perceived discrepancy between expectations and the actual performance of the product (Richard \& Oliver, 1999; Tse \& Wilton, 1988). In addition, satisfaction of customer in fact is how clients evaluate the continuing performance.(Gustafsson, Johnson \& Roos, 2005). However, customer satisfaction become as an important factor to gain success and competitive advantage for all manufacturing and service organizations. (Hennig-Thurau \& Klee, 1997).

Another definition is provided by Oliver (1997) where they defined the customer satisfaction as the customer's reaction to the state of satisfaction and customer's judgment of satisfaction level". Evolution of Customer satisfaction is very vital in all business around the world in today. Based on Deng et al., (2009) the ability to achieve a high level of satisfaction from the service providers is a key to differentiation of products or services and developing well-built relationship with clients. A customer loyalty to service provides comes from customer satisfaction.

\section{Quality of Services}

Quality has been recognized to be one of the key drivers of business efficiency and business excellence. Companies with high quality services are not only able to retain their existing customers but also increase their customer outreach by attracting new ones. Delivering high service quality is the main factor to ensure business success (Angelova \& Zekiri, 2011). The concept of service quality may vary and depend on some theoretical assumptions. That is, service quality has been defined by various academic scholars under their own theoretical assumptions. For instance, Parasuraman et al., (1985) who developed the SERVQUAL instrument, which has 
been most widely adapted as a service quality measurement tool, defined perceived service quality as the overall judgment or the evaluation of the service.

Moreover, Asubonteng, McCleary and Swan (1996), defined service quality as "the difference between customers' expectations for service performance prior to the service encounter and their perceptions of the service received". Despite the extensive literature related to the service quality, there is no agreed upon definition of the service quality. The concept of quality has been a crucial factor in determining the customer satisfaction towards the products or services (Kim et al., 2006). Besides, the International Standards Organization (ISO) defined quality as "the totality of features and characteristics of products or services that bears on its ability to satisfy or imply customers' needs (Madill et al., 2002).

\section{SERVQUAL Model}

In examining the service quality, there are many models employed by the researchers. The Service Quality Model (SERVQUAL) is considered as the pioneer model in customer satisfaction measurement developed by Parasuraman et al., (1985). This model has been recognized as the most representative tool in approaching customer satisfaction issues. Initially, there are ten distinct dimensions of service quality, tangibles, reliability, responsiveness, competence, courtesy, credibility, security, access, communication and empathy. It was further developed by Parasurman et al., (1994) and the ten dimensions were combined to become five dimensions namely, Reliability, Responsiveness, Assurance, Empathy and Tangibles.

\section{CARTER Model}

Othman and Owen (2001) have extended the SERVQUAL model to consider the Shari'ah compliance dimension to measure customer satisfaction in Islamic banks. The new model named as CARTER which stands for Compliance, Assurance, Reliability, Tangible, Empathy and Responsiveness. CARTER model is based on the influence of Islamic teaching in rating the perceived quality of the products and service among the Muslim customers. CARTER model comprises 34 items to measure Shari'ah compliance with all the five original dimensions of SERVQUAL model. This study applied CARTER model, as target of study Islamic microfinance customers.

\subsection{Compliance}

According to Othman and Owen (2001), the Shari'ah compliance dimension CARTER model means to what extent the service or the product comply with the Islamic law and principles. In Islamic banking and finance industry principles such as no interest is the main issue that can determine whether a particular is acceptable or not.

For four decades, Islamic banks have been in existence alongside with conventional banks offering the same products and services (Othman \& Owen, 2001). While producing loans and mobilizing the deposits, all these operations are according to the Shari'ah law.

\subsection{Assurance}

Othman and Owen (2001) in the CARTER, like SERVQUAL model, used assurance to refer to polite and friendly staff providing financial advices, interior comfort of the bank, how easy to access the required information and how knowledgeable and experienced is the management team. Furthermore, in CARTER model, assurance was the second most important service quality dimension in Kuwait Islamic Finance House. However, assurance appeared to be a less important dimension in Al- Tamimi's (2003) study of UAE Islamic banks. Gronroos (1988) developed six key dimensions of service quality; assurance (professionalism and skills) was one of these six categories. Parasuraman et al., (1994) documented in their study that assurance dimension was ranked as the fourth dimension based on its perceived importance.

Parasurman et al., (1994) defined assurance as the knowledge and courtesy of employees and their ability to convey trust and confidence to the customers. Assurance in SERVQUAL model (1994) comprised three types of service quality dimensions from the original ten dimensions. These three types of service quality dimensions are:

- Courtesy which refers to staff conduct, politeness, respect, consideration, friendliness, clean and neat appearance of public contact personnel including receptionists and telephone operators.

- Competence which refers to staff knowledge and skill required to deliver a good service.

- Communication which refers to the verbal and written information the bank uses to explain its service. It refers to the level of effective communication between the bank and its customers. In so doing, employees of the bank have the willingness to adjust its language for different consumers based on their cultural backgrounds. 


\subsection{Reliability}

Parasurman et al., (1985) defined the reliability of services as the offering of the right service at the right time. This dimension reveals to what extent the company respect their promises to the customers. It also implies the trustworthiness of the services offered to the customers.

Newman (2001) defined the reliability as the hard quality dimension that specifies the perceived gap between the customers' expectations and the actual reality in terms of products and services. According to the past literature, the reliability can be reflected through some dimensions such as the account accuracy, keeping promises, meeting deadlines, providing a timely service, providing accurate information to the customers and improving cash machines. The availability and dependability and services, convenience and offering a wide range of products and services are considered as attributes of the reliability dimension. More importantly, the security of transactions and making the services conveniently available can be critical attributes of the reliability of the financial and services offered (Othman \& Owen, 2001).

\subsection{Tangibles}

The Tangibles dimension refers to the physical appearance and the availability of the equipments, personnels, and the availability of the required facilities and materials (Parasurman et al., 1988, 1991). This dimension is very much related to the overall image of the financial institutions and will be an influential factor in forming the perceived service quality. In general, tangibles also include physical representations of the service and the speed and efficiency of transactions. Angur et al., 1999; and Jun (2001) use tangibles also to refer to customer communications.

However, Al-Tamimi and Al-Amiri (2003) defined it in terms of the appearance of branches in terms of appeal and found it to be one of the most important dimensions. Othman and Owen (2001) included intangibles: external appearance, speed and efficiency of transactions, opening hours of operations, counter partition in the bank, and overdraft privileges on current accounts. However, opening hours of operations may be more acceptable as part of empathy, as in Jabnoun and Al Tamimi's study (2003). In addition, overdraft privileges on current accounts could be included with the reliability dimension. Cui et al., (2003) perceived the tangible dimension as a distinct aspect that shows the consistency across cultures.

\subsection{Empathy}

Empathy refers to the attention given to the customers to understand them and consider their needs. In general, They want to feel their importance to the organizations and be treated as partners (Parasurman et al., 1994). Essentially, the empathy dimension reveals to what extent the customers are special to an organization and how their feedback and comments can affect the overall processes. In their modified version of the SERVQUAL model, Parasurman et al., (1994) combined access, credibility and security in one dimension which was named as empathy as detailed in the following:

- Security: The freedom from danger and risk - physical safety (knowing that customers do not get mugged at the cash machine), financial security, answering where customers' records are kept, and confidentiality (meaning that dealings with the bank are kept private).

- Credibility: This is referring to the trustworthiness, honesty and reputation, keeping customers' interests at heart, the organization's name and reputation, the personal characteristics of contact personnel, the degree of hard sell involved in interactions with the customer, as well as understanding individual need and problems.

- Access: This requires that the service is easy to access to and is delivered on time. It also means that the services are easily approachable and convenient.

\subsection{Responsiveness}

Responsiveness is the staff willingness to help customers and provide prompt service (Parasurman et al., 1985-1994). This definition is supported by many authors such as Jabnoun and Al Tamimi 2003; Jun et al., 2001; Lam 2002; and Surshchandar et al., (2003) who have described responsiveness as the provision of prompt service. The Oxford dictionary identifies responsiveness as the quality of being responsive, reacting quickly, as a quality of people. In fact, the responsiveness to the customers reflects their importance to the organization offering the service. Customers need always answers to their questions and need the flexibility and customized services that meet their special needs.

Othman and Owen's study (2001) described responsiveness in the Islamic banking sector as knowledge of customer's business or willingness to help, the way staff treats customers, availability of credit on favorable terms, and branching, also quick and fast counter service. Also, Al- Tamimi et al., (2003) modified SERVQUAL 
in their study and found that one of their dimensions consisted of items that were part of the two original dimensions of responsiveness and empathy in the original SERVQUAL. Avkiran (1994) ranked responsiveness first when examining the six dimension model of service quality in the banking industry. However, the model items were reduced and responsiveness items included under other dimensions. Angur et al., (1999) ranked responsiveness as the most important dimension. However, Lam (2002) ranked responsiveness as the fourth dimension.

\section{Theoretical Framework and Hypotheses Development}

\subsection{Theoretical Framework}

Measuring customer satisfaction of Islamic microfinance Institutions is an important to develop a good strategy for reducing poverty level in the society, and help governments in the developing countries such as Yemen, to take care of the customers of IMFI, As mentioned before the target of IMFI are poor customers and those who can't access to formal banks, usually formal banks require advanced requirements, that poor people can't access to their financial services, the variables showed in figure "1" try to measurement the SMEs satisfaction through IMFI in Yemen, we developed the model depending on previous studies, Parasuraman, et al., (1985) developed model of service quality has ten dimension to measure the service quality in various service sector, in their next study in 1988 they combined the ten diminution in just five, Assurance, Reliability, Tangibles, Empathy and Responsiveness, this model called SERVQUAL, there are many researchers used SERVQUAL model that has only five dimensions, and they applied in financial sector by focusing in commercial banks. For instance, a study conducted by Tahir and Bakar, (2007) mentioned to the service quality gap and customer satisfaction of commercial banks in Malaysia they found that customers were slightly satisfied with the overall service quality of the bank.

In addition, Othman and Owen, (2001) added "compliance" to the previous model of Parasuraman, Zeithaml, and Berry, to measure the service quality in Islamic finance institutions, So they use six diminutions, Compliance, Assurance, Reliability, Tangibles, Empathy and Responsiveness, there are many researches applied this model to measure the customer satisfaction in Islamic banks in varying countries, For instance study conducted by Osman et al., (2009) investigated customer satisfaction in Malaysian Islamic Banking.

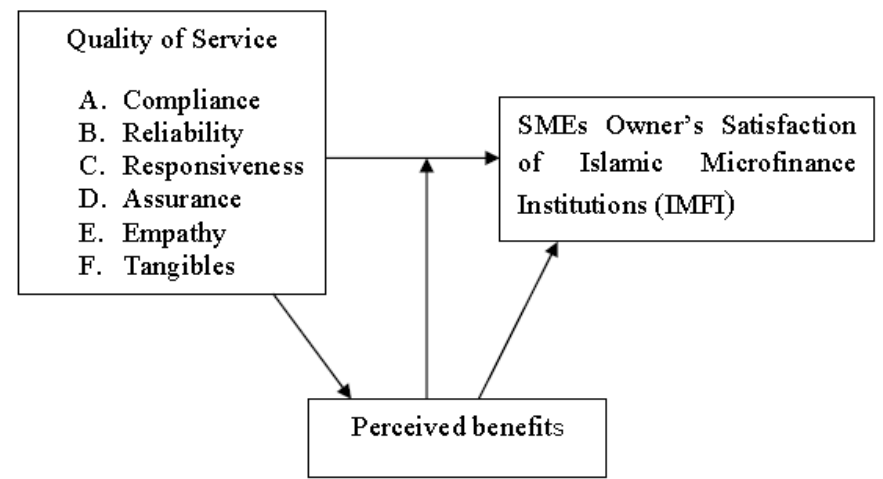

Figure 1. Theoretical framework of small \& medium enterprises (SMEs) owners' satisfaction on Islamic microfinance system in Yemen

\subsubsection{Service Quality and SMEs Owners' Satisfaction}

Ramdhani and Kurniati (2011) studied customer satisfaction of Islamic Sharia Banks in Indonesia, found that all the six factors of CARTER model are satisfied by $80.10 \%$ which consists of quality of service offered by this bank. Shafie, Azmi, \& Haron, (2004) showed that in their study customers are satisfied by very high in reliability by $91 \%$, and the other five dimensions, compliance $75 \%$, Assurance $77 \%$, Tangible $75 \%$, Empathy $80 \%$ and responsiveness $81 \%$, that means the customers of BIMB almost satisfied with it is services offered.

Othman and Owen (2001) study the compliance with Islamic law it was the most important factor for Kuwait Financial House's customers, they said KFH has to run on Islamic law principles. Compliance dimension will affect in SMEs owners' satisfaction on Islamic microfinance institutions, because Yemen is a Muslim country and the people looking for those institutions following Islamic law perspective. Compliance has low importance of Malaysian Islamic Baking's customers argued by Osman et al., (2009). Othman and Owen (2001) found that reliability is most important to measure customer satisfaction in Malaysian Islamic Banking. In addition, Newman (2001) called Reliability a hard quality dimension, ranked as the first dimension on service quality 
model SERVQUAL, and with the largest gap between customer expectations and perceptions. Moreover, Vibha and Nravichandran (2011), found that the banks need to focus more on reliability of the service in order to keep their customer satisfied in Indian retail banking.

A study conducted by Khalid, Mahmood, Abbas, and Hussain, (2011) reported high satisfaction of conventional banks' customers in the responsiveness. Even though responsiveness is one of the difficult dimensions to evaluate, Newman's study showed a significant gap between perception and expectation. In SERVQUAL model 1994, responsiveness ranked as the third dimension. In addition, Angur et al., (1999) ranked responsiveness dimension is as the most important dimension. However, Lam (2002) ranked responsiveness as the fourth dimension.

Othman and Owen (2001) showed that assurance is the second important factor for the service quality of KFH's customers. Osman et al., (2009) showed that assurance has a high effect on customer satisfaction in the Malaysian Islamic banking system. In addition, Gronroos (1988) developed six key dimensions of service quality, professionalism and skills (i.e assurance) one of these six category was first element. While, Parasuraman et al., (1994) documented in their study assurance dimensions ranked as fourth element. However, assurance appeared to be a less important dimension in Al- Tamimi's study of UAE Islamic banks (2003). Moreover, Parasurman et al., (1994) reported that assurance is likely to be particularly important for services that the customer perceives as connecting high risk or about which they suffer uncertain about their skills to evaluate outcomes such as in banking, insurance, legal and medical services.

Parasurman et al., (1994), defined empathy as "the helpful, individualized attention the organization provides its customers". Empathy has a low effect on customer's satisfaction of Malaysian Islamic Banking customers based on Osman et al., (2009). In addition, Al-Tamimi and Al-Amiri (2003) studied the service quality of UAE Islamic banks resulted in three dimensions, empathy was one of them, and consisted of items that were part of two original SERVQUAL dimensions of responsiveness and empathy.

Moreover, Newman's study (2001) of a UK high street bank found that empathy was the third dimension in which customer expectations were not being met. Additionally, Avkiran (1994) designed and examined six dimensions in a model of service quality in banking and empathy and access were the second and fourth dimensions. As well as, Parasuraman et al., (1994) in SERVQUAL ranked empathy as the fifth dimension. However, Lam (2002) ranked empathy as the third dimension. Finally, Jabnoun and Al Tamimi (2003) found empathy to be the second dimension in UAE commercial banks.

According to Othman and Owen (2001) tangible is the least important factor from all the six dimensions, the KFH's customer focus by a run on Islamic law and principles, also it has law effect on service quality. Osman et al., (2009) confirmed that customers of the Malaysian Islamic Banking system looking for Tangibles to satisfy their needs.

According to Khalid et al., (2011) found lower satisfaction of conventional banks 'customers intangible area, the three banks mentioned in Khalid's study have to redesign their strategy about customer satisfaction with respect to service quality. In addition, Al-Tamimi and Al-Amiri (2003) defined tangibles it in terms of the look of branches in conditions of appeal and found it to be one of the most important dimensions. Moreover, Cui et al., (2003) perceived the tangible dimension as different features that have to show consistency across cultures. As well, Newman found that tangibles exceeded customers' expectations in UK banks. Finally, Jabnoun and Al Tamimi (2003) study found that tangibles were equally significant with empathy.

Based on the aforementioned arguments, we hypothesize that:

\section{$H_{1}$. Service quality has a positive significant effect on the SMEs owners'satisfaction on Islamic microfinance system}

\section{$H_{2 .}$ Service quality has a positive significant effect on the perceived benefits}

\subsubsection{Service Quality and Perceived Benefit with SMEs Owners' Satisfaction}

Heaney and Goldsmith (1999) defined Perceived Benefits as the value of the products and services as deemed by individuals and organizations. Many benefits such as customer service, competitive advantage, lower costs, functionality, multi-country needs, scalability, expanded capacity, and facilitating operational change can form the perception of the customer towards the services or products offered. However, Heaney and Goldsmith (1999) found that there is a positive relationship between perceived benefit and information search for banking services. This is so since the consumers search for more information when they perceive the benefits that can be obtained from the offered services. 
In addition, Punj and Staelin 1983; Srinivasan and Ratchford (1991) found that information search is positively and significantly related to the buying behavior of the customers. So, customers used to search for more information if they perceive potential opportunities to save cost and time (Schmidt \& Spreng, 1996).

In general, the perceived benefits are expected to enhance the satisfaction of customers regarding the service quality provided. In addition, the higher the perceived benefits the higher effect of the business development practices on the customers' satisfaction. Therefore, the following hypotheses are presented for future empirical investigation.

\section{$H_{3}$. The perceived benefit has a positive significant effect on the SMEs owner satisfaction on IMFI. \\ $H_{4}$. The perceived benefit mediates the effect of service quality and SMEs owner satisfaction on IMFI. \\ $H_{5}$. The perceived benefit moderates the relationship between quality of services and SMEs owner satisfaction on IMFI.}

\section{Population and Sampling}

The population of this study was the SMEs owners who deal with Islamic Microfinance Institutions. In Yemen there are 12 Microfinance providers offering microfinance services all of them listed under Social Fund of Development (SFD) in Yemen. MFI aims to support poor people by financing their businesses or helping them in establishing new businesses. The total population of this study was the customers dealing with Islamic Microfinance institutions. Specifically, the total population of this study is 34124 SMEs who deals with Islamic microfinance institutions. The questionnaire meant to measure the SMEs' owners' satisfaction on the Islamic banks' services was distributed to 250 targeted respondents randomly selected from the list of Islamic microfinance providers. Out of that number 153 was returned and used for the analysis.

\section{Measurement and Instrumentation}

Actually, the Likert scale measure has been one of the most commonly used scales to examine the customer's satisfaction, (Al-Marri et al., 2007). Thus, multiple-item Likert scale was considered to be an appropriate interval scale to measure the behavior of variables included in this study (Al-Marri et al., 2007). Specifically, to achieve the objectives of this study, a five-point Likert scale ranging from " 1 " (strongly disagree) to "5" (strongly agree) for satisfaction.

The choice of a five-point Likert scale was supported, according to Al-Marri et al. (2007), by the fact that it is commonly used in the previous studies related to the customer's satisfaction. Additionally, Likert scale is easy for respondents to react and report their perceptions regarding attitudes, behaviors and assessments. In the following sub-sections, this study discussed the measures used to measure SMEs satisfaction of IMFI in Yemen.

\subsection{Service Quality}

The measurement of service quality was derived from the relevant studies in the customer satisfaction literature. However, the measure used in this study was adapted from the measures used by Parasuraman et al. (1991) and Othman and Owen, (2001). These measures were used to measure the service quality in the financial organizations and the service sector. There are 24 items used to measure the service quality of Islamic microfinance institutions in Yemen.

\subsection{Perceived Benefits}

The measurement of perceived benefits was derived from the relevant literature. However, the deployed measure used in this study was adapted from the measures used by Heaney and Goldsmith (1999). Six items constitute the measure of the perceived benefits.

\subsection{Overall Customer Satisfaction}

The measurement of overall satisfaction was adapted from the measures used by Angelova and Zekiri (2011). These measures were used to measure the overall satisfaction of SMEs, there are 5 items used to measure the Overall satisfaction of SMEs in Yemen.

\section{Statistical Analysis and Findings}

Structural Equations Modeling Partial Least Squares (PLS) approach was used SmartPLS 2.0 to establish the measurement validity and reliability before the model has been examined and the hypotheses have been tested.

Following the two-step approach suggested by Chin (1998), this study attempted to examine the structural model containing the service quality, perceived benefits and satisfaction. 


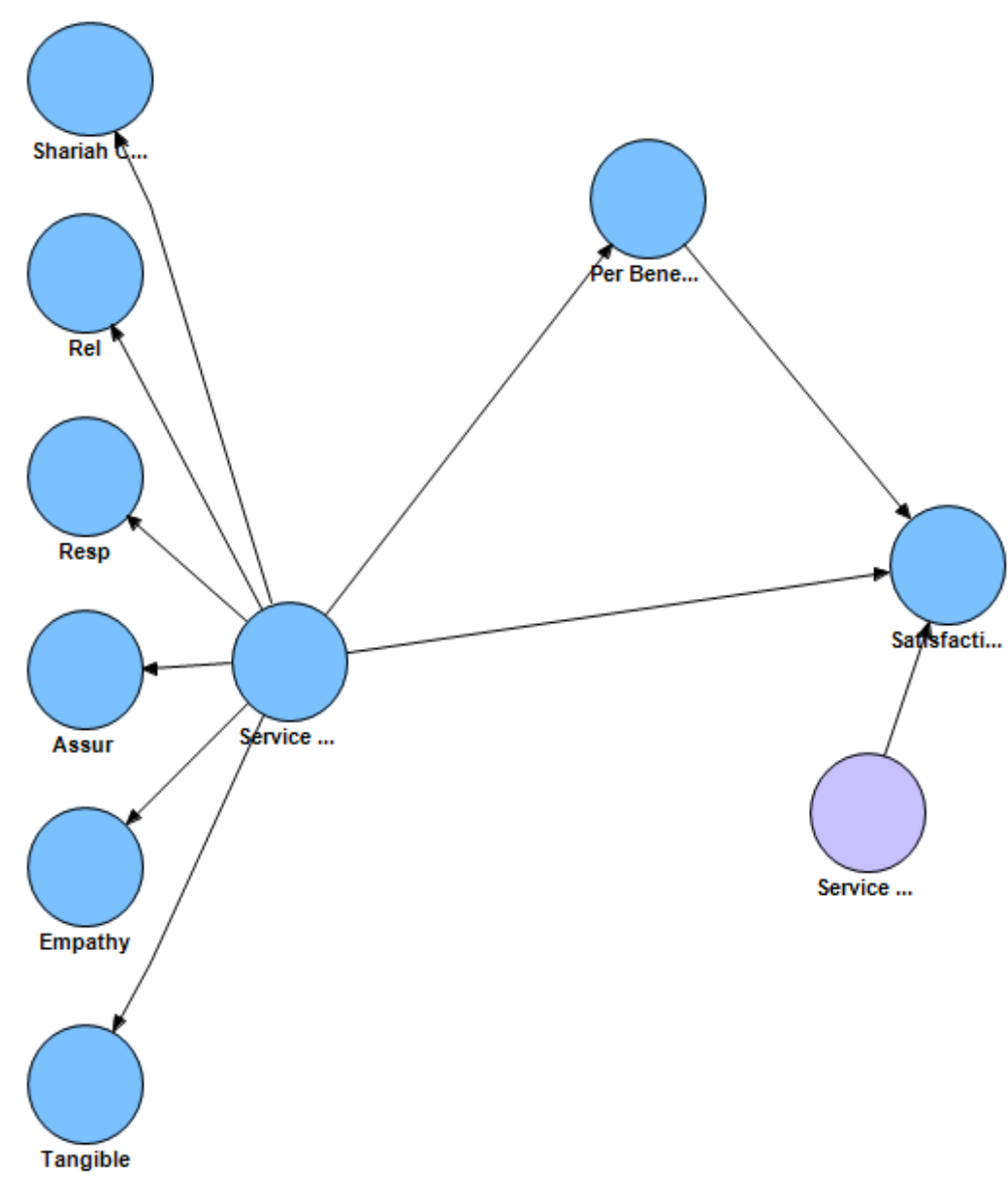

Figure 2. The research model

As it is the usual practice in the literature, the construct validity and reliability were established through the measurement analysis before the hypotheses have been examined.

\subsection{The Measurement Model}

In order to establish the goodness of measurement, the content validity and the construct validity were confirmed as discussed in the following.

\subsubsection{The Content Validity}

As defined in the multivariate analysis literature, the content validity of a construct implies that all the items used to measure a construct should show high loadings on their respective constructs. Therefore, following the suggestion of Hair et al., (2010) and Chin (1998), the factor loading should be used to evaluate the content validity. This implies that if some items have higher loadings on other constructs that the ones they belong to, these items will be candidates for deletion. Tables 1 and 2 showed that all the variables significantly loaded on their respective constructs and this confirmed that the measurement model used possesses the required content validity. 
Table 1. Loading and cross-loadings of the items

\begin{tabular}{|c|c|c|c|c|c|c|c|c|}
\hline $\begin{array}{l}\text { Variabl } \\
\mathrm{e}\end{array}$ & $\begin{array}{c}\text { Assuranc } \\
\mathrm{e}\end{array}$ & $\begin{array}{c}\text { Empath } \\
\mathrm{y}\end{array}$ & $\begin{array}{c}\text { Satisfactio } \\
\mathrm{n}\end{array}$ & $\begin{array}{l}\text { Perceive } \\
\text { d } \\
\text { Benefits }\end{array}$ & $\begin{array}{c}\text { Reliabilit } \\
y\end{array}$ & $\begin{array}{c}\text { Responsivenes } \\
\mathrm{S}\end{array}$ & $\begin{array}{c}\text { Shariah } \\
\text { Complianc } \\
\text { e }\end{array}$ & $\begin{array}{c}\text { Tangibl } \\
\mathrm{e}\end{array}$ \\
\hline AS5 & 0.796 & 0.552 & 0.494 & 0.526 & 0.510 & 0.496 & 0.463 & 0.507 \\
\hline AS6 & 0.671 & 0.347 & 0.392 & 0.341 & 0.386 & 0.317 & 0.411 & 0.389 \\
\hline AS7 & 0.781 & 0.590 & 0.458 & 0.408 & 0.580 & 0.450 & 0.460 & 0.472 \\
\hline AS8 & 0.756 & 0.358 & 0.427 & 0.402 & 0.444 & 0.381 & 0.355 & 0.442 \\
\hline EM17 & 0.396 & 0.636 & 0.450 & 0.447 & 0.381 & 0.442 & 0.318 & 0.441 \\
\hline EM18 & 0.494 & 0.792 & 0.447 & 0.460 & 0.511 & 0.574 & 0.399 & 0.534 \\
\hline EM19 & 0.540 & 0.805 & 0.599 & 0.517 & 0.573 & 0.483 & 0.450 & 0.494 \\
\hline EM20 & 0.480 & 0.817 & 0.490 & 0.403 & 0.485 & 0.593 & 0.479 & 0.605 \\
\hline OS51 & 0.526 & 0.568 & 0.804 & 0.549 & 0.567 & 0.497 & 0.575 & 0.375 \\
\hline OS52 & 0.487 & 0.471 & 0.811 & 0.566 & 0.604 & 0.526 & 0.572 & 0.512 \\
\hline OS53 & 0.418 & 0.515 & 0.820 & 0.482 & 0.434 & 0.409 & 0.492 & 0.312 \\
\hline OS54 & 0.466 & 0.546 & 0.874 & 0.672 & 0.593 & 0.515 & 0.612 & 0.516 \\
\hline OS55 & 0.515 & 0.555 & 0.785 & 0.579 & 0.609 & 0.519 & 0.497 & 0.453 \\
\hline RB45 & 0.351 & 0.368 & 0.250 & 0.568 & 0.406 & 0.340 & 0.275 & 0.321 \\
\hline RB46 & 0.262 & 0.389 & 0.479 & 0.752 & 0.375 & 0.427 & 0.333 & 0.310 \\
\hline RB47 & 0.423 & 0.377 & 0.496 & 0.778 & 0.479 & 0.404 & 0.413 & 0.395 \\
\hline RB48 & 0.393 & 0.433 & 0.531 & 0.746 & 0.491 & 0.336 & 0.484 & 0.306 \\
\hline RB49 & 0.529 & 0.536 & 0.624 & 0.708 & 0.556 & 0.559 & 0.662 & 0.517 \\
\hline RB50 & 0.368 & 0.363 & 0.486 & 0.667 & 0.400 & 0.363 & 0.362 & 0.207 \\
\hline RE10 & 0.468 & 0.475 & 0.520 & 0.384 & 0.785 & 0.528 & 0.357 & 0.477 \\
\hline RE11 & 0.485 & 0.436 & 0.459 & 0.536 & 0.684 & 0.450 & 0.431 & 0.476 \\
\hline RE12 & 0.474 & 0.462 & 0.438 & 0.402 & 0.714 & 0.516 & 0.292 & 0.537 \\
\hline RE9 & 0.453 & 0.493 & 0.591 & 0.567 & 0.731 & 0.511 & 0.565 & 0.454 \\
\hline RES21 & 0.447 & 0.489 & 0.441 & 0.428 & 0.522 & 0.784 & 0.396 & 0.612 \\
\hline RES22 & 0.461 & 0.542 & 0.519 & 0.515 & 0.510 & 0.746 & 0.424 & 0.546 \\
\hline RES23 & 0.393 & 0.532 & 0.435 & 0.465 & 0.501 & 0.788 & 0.404 & 0.538 \\
\hline RES24 & 0.421 & 0.571 & 0.491 & 0.420 & 0.607 & 0.797 & 0.435 & 0.614 \\
\hline $\mathrm{SC} 1$ & 0.394 & 0.411 & 0.473 & 0.512 & 0.491 & 0.477 & 0.772 & 0.441 \\
\hline $\mathrm{SC} 2$ & 0.424 & 0.435 & 0.531 & 0.461 & 0.466 & 0.424 & 0.854 & 0.366 \\
\hline $\mathrm{SC} 3$ & 0.486 & 0.447 & 0.566 & 0.532 & 0.403 & 0.424 & 0.746 & 0.377 \\
\hline $\mathrm{SC} 4$ & 0.441 & 0.378 & 0.516 & 0.421 & 0.382 & 0.302 & 0.707 & 0.241 \\
\hline TA13 & 0.396 & 0.432 & 0.300 & 0.337 & 0.506 & 0.558 & 0.291 & 0.779 \\
\hline TA14 & 0.474 & 0.483 & 0.369 & 0.291 & 0.568 & 0.605 & 0.233 & 0.729 \\
\hline TA15 & 0.441 & 0.523 & 0.408 & 0.389 & 0.458 & 0.528 & 0.394 & 0.765 \\
\hline TA16 & 0.473 & 0.570 & 0.508 & 0.463 & 0.434 & 0.503 & 0.465 & 0.681 \\
\hline
\end{tabular}


Table 2. T value results

\begin{tabular}{|c|c|c|c|c|c|}
\hline Construct & Items & Loadings & Standard Error & T Value & P Value \\
\hline \multirow[t]{4}{*}{ Assurance } & AS5 & 0.796 & 0.033 & 24.422 & 0.000 \\
\hline & AS6 & 0.671 & 0.044 & 15.293 & 0.000 \\
\hline & AS7 & 0.781 & 0.029 & 27.003 & 0.000 \\
\hline & AS8 & 0.756 & 0.045 & 16.874 & 0.000 \\
\hline \multirow[t]{4}{*}{ Empathy } & EM17 & 0.636 & 0.056 & 11.351 & 0.000 \\
\hline & EM18 & 0.792 & 0.034 & 23.425 & 0.000 \\
\hline & EM19 & 0.805 & 0.033 & 24.559 & 0.000 \\
\hline & EM20 & 0.817 & 0.033 & 24.449 & 0.000 \\
\hline \multirow[t]{5}{*}{ Satisfaction } & OS51 & 0.804 & 0.033 & 24.095 & 0.000 \\
\hline & OS52 & 0.811 & 0.027 & 30.390 & 0.000 \\
\hline & OS53 & 0.820 & 0.029 & 28.185 & 0.000 \\
\hline & OS54 & 0.874 & 0.017 & 50.661 & 0.000 \\
\hline & OS55 & 0.785 & 0.035 & 22.234 & 0.000 \\
\hline \multirow[t]{6}{*}{ Perceived Benefits } & RB45 & 0.568 & 0.070 & 8.147 & 0.000 \\
\hline & RB46 & 0.752 & 0.041 & 18.387 & 0.000 \\
\hline & RB47 & 0.778 & 0.036 & 21.635 & 0.000 \\
\hline & RB48 & 0.746 & 0.038 & 19.502 & 0.000 \\
\hline & RB49 & 0.708 & 0.032 & 22.038 & 0.000 \\
\hline & RB50 & 0.667 & 0.052 & 12.880 & 0.000 \\
\hline \multirow[t]{4}{*}{ Reliability } & RE10 & 0.785 & 0.038 & 20.442 & 0.000 \\
\hline & RE11 & 0.684 & 0.049 & 13.990 & 0.000 \\
\hline & RE12 & 0.714 & 0.056 & 12.838 & 0.000 \\
\hline & RE9 & 0.731 & 0.044 & 16.565 & 0.000 \\
\hline \multirow[t]{4}{*}{ Responsiveness } & RES21 & 0.784 & 0.035 & 22.638 & 0.000 \\
\hline & RES22 & 0.746 & 0.040 & 18.512 & 0.000 \\
\hline & RES23 & 0.788 & 0.034 & 23.489 & 0.000 \\
\hline & RES24 & 0.797 & 0.032 & 25.185 & 0.000 \\
\hline \multirow[t]{4}{*}{ Shariah Compliance } & $\mathrm{SC} 1$ & 0.772 & 0.036 & 21.606 & 0.000 \\
\hline & $\mathrm{SC} 2$ & 0.854 & 0.026 & 32.617 & 0.000 \\
\hline & $\mathrm{SC} 3$ & 0.746 & 0.037 & 20.439 & 0.000 \\
\hline & $\mathrm{SC} 4$ & 0.707 & 0.047 & 15.122 & 0.000 \\
\hline \multirow[t]{4}{*}{ Tangible } & TA13 & 0.779 & 0.041 & 19.106 & 0.000 \\
\hline & TA14 & 0.729 & 0.047 & 15.501 & 0.000 \\
\hline & TA15 & 0.765 & 0.041 & 18.889 & 0.000 \\
\hline & TA16 & 0.681 & 0.053 & 12.733 & 0.000 \\
\hline
\end{tabular}

\subsubsection{The Convergent Validity}

The convergent validity is defined to indicate the extent to which a set of items converges in measuring a particular construct (Bagozzi \& Yi, 1988; Hair et al., 2010). Based on the SEM literature, the convergent validity can be confirmed by examining the item's reliability, composite reliability and the average variance extracted. That is, the items of each construct are highly loaded and statistically significant in measuring their respective constructs with at least 0.7 factor loadings, the composite reliability of each construct is at least 0.819 exceeding the cut off value of 0.7 and the average variance extracted (AVE) for each construct is at least 0.5 . These results indicate that the measurement model has an adequate convergent validity (Bagozzi \& Yi, 1988; Hair et al., 2010).

The results in Table 3 showed that the composite reliability values of all the constructs exceeded the recommended value of 0.7 and all the AVE values are more than 0.5. As a result, it can be confirmed that the measurement model has an adequate level of convergent validity. 
Table 3. Convergent validity analysis

\begin{tabular}{|c|c|c|c|c|c|}
\hline Construct & Items & Loadings & Cronbach's Alpha & $\mathrm{CR}^{\mathrm{a}}$ & $\mathrm{AVE}^{\mathrm{b}}$ \\
\hline \multirow[t]{4}{*}{ Assurance } & AS5 & 0.796 & 0.744 & 0.839 & 0.566 \\
\hline & AS6 & 0.671 & & & \\
\hline & AS7 & 0.781 & & & \\
\hline & AS8 & 0.756 & & & \\
\hline \multirow[t]{4}{*}{ Empathy } & EM17 & 0.636 & 0.762 & 0.849 & 0.587 \\
\hline & EM18 & 0.792 & & & \\
\hline & EM19 & 0.805 & & & \\
\hline & EM20 & 0.817 & & & \\
\hline \multirow[t]{5}{*}{ Satisfaction } & OS51 & 0.804 & 0.878 & 0.911 & 0.672 \\
\hline & OS52 & 0.811 & & & \\
\hline & OS53 & 0.820 & & & \\
\hline & OS54 & 0.874 & & & \\
\hline & OS55 & 0.785 & & & \\
\hline \multirow[t]{6}{*}{ Perceived Benefits } & RB45 & 0.568 & 0.800 & 0.856 & 0.499 \\
\hline & RB46 & 0.752 & & & \\
\hline & RB47 & 0.778 & & & \\
\hline & RB48 & 0.746 & & & \\
\hline & RB49 & 0.708 & & & \\
\hline & RB50 & 0.667 & & & \\
\hline \multirow[t]{4}{*}{ Reliability } & RE10 & 0.785 & 0.705 & 0.819 & 0.532 \\
\hline & RE11 & 0.684 & & & \\
\hline & RE12 & 0.714 & & & \\
\hline & RE9 & 0.731 & & & \\
\hline \multirow[t]{4}{*}{ Responsiveness } & RES21 & 0.784 & 0.784 & 0.860 & 0.607 \\
\hline & RES22 & 0.746 & & & \\
\hline & RES23 & 0.788 & & & \\
\hline & RES24 & 0.797 & & & \\
\hline \multirow[t]{4}{*}{ Shariah Compliance } & $\mathrm{SC} 1$ & 0.772 & 0.772 & 0.854 & 0.596 \\
\hline & $\mathrm{SC} 2$ & 0.854 & & & \\
\hline & $\mathrm{SC} 3$ & 0.746 & & & \\
\hline & $\mathrm{SC} 4$ & 0.707 & & & \\
\hline \multirow[t]{4}{*}{ Tangible } & TA13 & 0.779 & 0.722 & 0.828 & 0.547 \\
\hline & TA14 & 0.729 & & & \\
\hline & TA15 & 0.765 & & & \\
\hline & TA16 & 0.681 & & & \\
\hline
\end{tabular}

a: $\mathrm{CR}=(\Sigma$ factor loading $) 2 /\{(\Sigma$ factor loading $) 2)+\Sigma$ (variance of error $)\}$

b: AVE $=\Sigma$ (factor loading $) 2 /(\Sigma$ (factor loading $) 2+\Sigma$ (variance of error $)\}$

\subsubsection{The Discriminant Validity}

The discriminant validity is defined to be the degree to which a set of items can differentiate a construct from other constructs. This means that variance shared among the items of each construct should be greater than the variance shared with other constructs (Compeau et al., 1999). Fornell and Larcker (1981) suggested a criterion to examine the discriminant validity. As illustrated in Table 4, diagonal elements are the square roots of the average variance extracted and the below the diagonal element are the correlation amongst the variables. The comparison to be made and the discriminant validity can be assumed if the diagonal elements are higher than other off-diagonal elements in their respective rows and columns. In fact, the results in the correlation matrix illustrated in Table 4 ensure that the discriminant validity is confirmed. 
Table 4. Correlations and discriminant validity

\begin{tabular}{lcccccccc}
\hline Constructs & 1 & 2 & 3 & 4 & 5 & 6 & 7 & 8 \\
\hline 1) Assurance & $\mathbf{0 . 7 5 2}$ & & & & & & & \\
2) Empathy & 0.626 & $\mathbf{0 . 7 6 6}$ & & & & & & \\
3) Perceived Benefits & 0.562 & 0.593 & $\mathbf{0 . 7 0 7}$ & & & & & \\
4) Reliability & 0.645 & 0.641 & 0.649 & $\mathbf{0 . 7 2 9}$ & & & & \\
5) Responsiveness & 0.553 & 0.686 & 0.586 & 0.689 & $\mathbf{0 . 7 7 9}$ & & & \\
6) Satisfaction & 0.591 & 0.648 & 0.701 & 0.691 & 0.606 & $\mathbf{0 . 8 2 0}$ & & \\
7) Shariah Compliance & 0.563 & 0.542 & 0.626 & 0.567 & 0.533 & 0.674 & $\mathbf{0 . 7 7 2}$ & \\
8) Tangible & 0.605 & 0.680 & 0.501 & 0.666 & 0.743 & 0.537 & 0.468 & $\mathbf{0 . 7 4 0}$ \\
\hline
\end{tabular}

\subsubsection{Predictive Relevance of the Model}

To assess the predictive power of the model, $R^{2}$ and Cross-Validated redundancy were utilized. $R^{2}$ value indicates the amount of variance in the endogenous variable that is explained by the exogenous variables. The results reported in Table 5 Showed that $\mathrm{R}^{2}$ showed that $62.3 \%$ of the satisfaction was explained by the service quality and perceived benefits. In addition, $50.4 \%$ of the perceived benefits variable was accounted for by the service quality. According to the guidelines suggested by Cohen (1988), 0.26 substantial, 0.13 moderate and 0.02 weak; both values of the $\mathrm{R}^{2}$ are considered substantial indicating the power of variables included in the model in explaining the satisfaction.

Besides $\mathrm{R}^{2}$, the quality of the model can be assessed based on the Cross-Validated Redundancy values. These values can be obtained by running the Blindfolding procedures in SmartPLS which was used to generate the cross-validate communality and cross-validated redundancy. The Blindfolding procedure is based on removing some of the data then estimating them as missing values. The estimated parameters are then used to reconstruct the missing data points. After that, the comparison will be held to assess how close the real from the implied results and the $\mathrm{Q}^{2}$ values will be calculated. Practically, if the estimation of the data points is obtained by the latent variables that predict the block in question, the output is the cross-validated redundancy.

Table 5. Prediction Relevance of the Model

\begin{tabular}{lccc}
\hline Endogenous & R Square & Cross-Validated Redundancy & Cross-Validated Communality \\
\hline Perceived Benefits & 0.504 & 0.240 & 0.500 \\
Satisfaction & 0.623 & 0.412 & 0.678 \\
\hline
\end{tabular}

Following the suggestion of Fornell and Cha (1994), a model is said to have the predictive quality if the cross-redundancy values were found to be more than zero, otherwise the predictive relevance of the model cannot be confirmed. The results in Table 5 showed that the obtained cross validated redundancy of the perceived benefits and satisfaction was found to be 0.5 and 0.678 respectively. These results support the claim that the model has an adequate prediction quality.

\subsubsection{Goodness of Fit (GoF) of the Model}

Dislike CB-SEM, PLS-SEM has only one measure of goodness of fit which was defined to be the global fit measure by Tenenhaus et al. (2005). It is the geometric mean of the average variances extracted and the average $\mathrm{R}^{2}$ for the endogenous variables as given in the following formula

$$
\text { Gof }-\sqrt{\left(\overline{R^{2}} \times \overline{A V E}\right)}
$$

Particularly, the GoF value of this model was found to be 0.608 which is considered large when compared to the baseline values suggested by Wetzels et al., (2009) ( small $=0.1$, medium $=0.25$, large $=0.36$ ). The results showed that the model goodness of fit measure based on the average variance explained is large which indicate an adequate level of global PLS model validity. 


\subsection{The Structural Model and Hypothesis Testing}

After the construct validity and construct reliability have been established, the next step was to test the hypotheses of the study by running PLS Algorithm and Bootstrapping Algorithm in SmartPLS 2.0. The results were reported as in Figure 3, Figure 4, and Table 6.

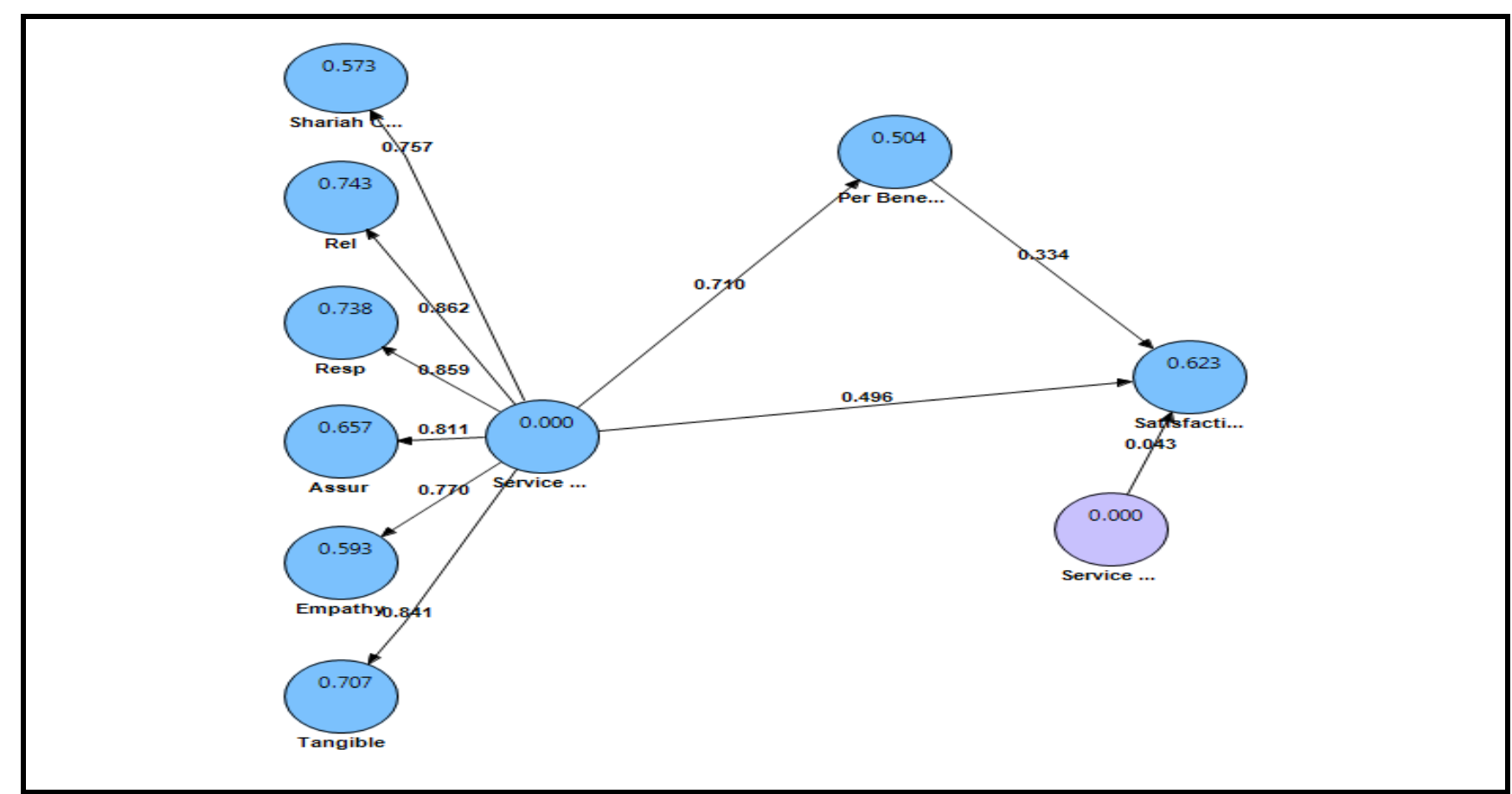

Figure 3. Path coefficient results

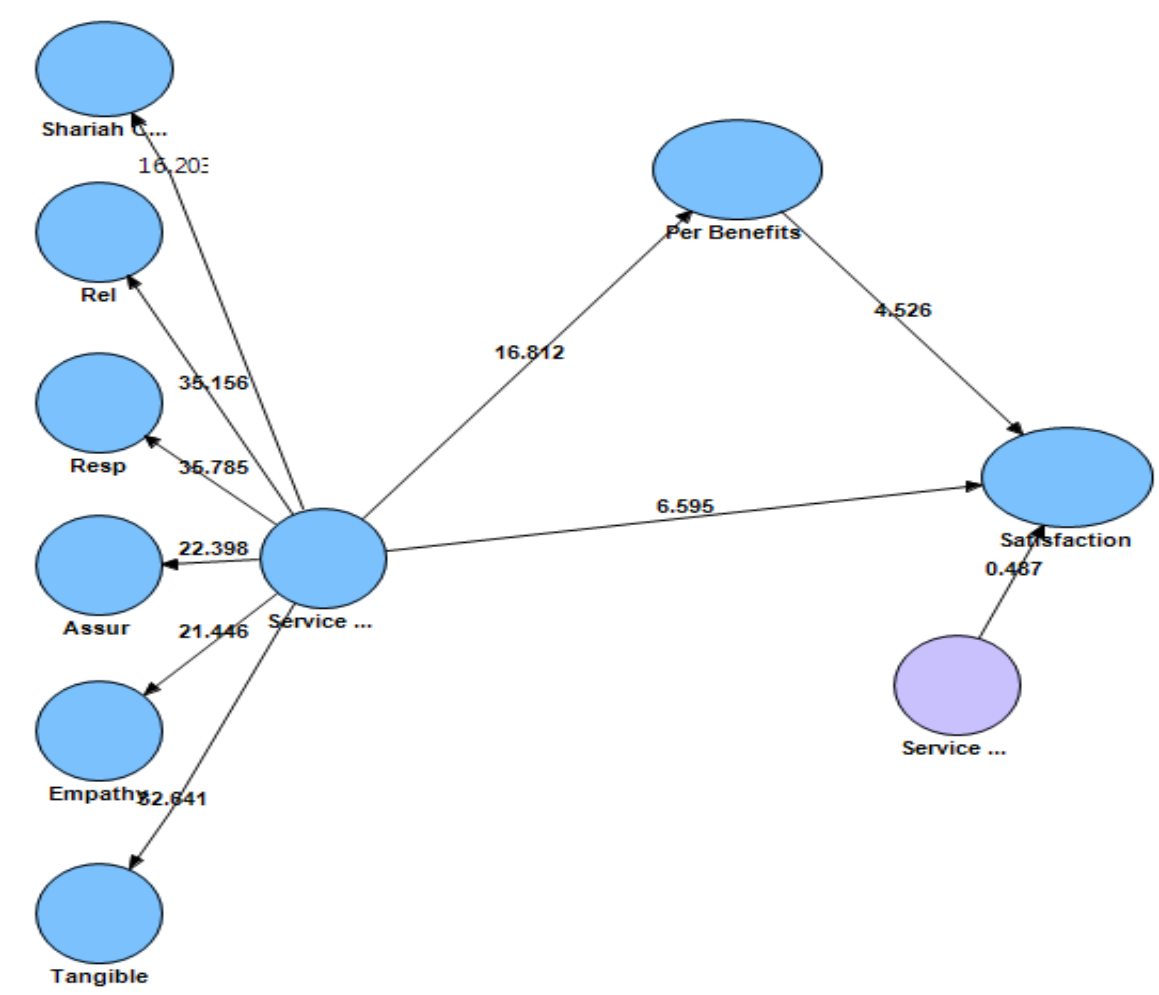

Figure 4. Path coefficients T values 
Table 6. The results of the hypothesis testing

\begin{tabular}{|c|c|c|c|c|c|c|c|c|}
\hline $\begin{array}{l}\text { Hyp. } \\
\text { No }\end{array}$ & \multicolumn{3}{|l|}{ Hypothesis } & $\begin{array}{c}\text { Path } \\
\text { Coefficient }\end{array}$ & $\begin{array}{c}\text { Standard } \\
\text { Error }\end{array}$ & $\begin{array}{c}T \\
\text { Value }\end{array}$ & $\begin{array}{c}\mathbf{P} \\
\text { Value }\end{array}$ & Decision \\
\hline $\mathrm{H}_{1}$ & \multicolumn{3}{|c|}{$\begin{array}{l}\text { Service Quality ---> Perceived } \\
\text { Benefits }\end{array}$} & $0.710 * * *$ & 0.042 & 16.812 & 0.000 & Supported \\
\hline $\mathrm{H}_{2}$ & $\begin{array}{l}\text { Perceived } \\
\text { Satisfaction }\end{array}$ & Benefits & $--->$ & $0.334 * * *$ & 0.074 & 4.526 & 0.000 & Supported \\
\hline $\mathrm{H}_{3}$ & $\begin{array}{l}\text { Service } \\
\text { Satisfaction }\end{array}$ & Quality & $--->$ & $0.496 * * *$ & 0.075 & 6.595 & 0.000 & Supported \\
\hline
\end{tabular}

As illustrated in Figures 2, 3 and Table 6 service quality has a positive and significant effect on the perceived benefits at the 0.001 level of significance $(\beta=0.710, t=16.812, p<0.001)$. The results also show that perceived benefits have a positive and significant effect on the satisfaction of customers at the 0.001 level of significance $(\beta=0.334, t=4.526, p<0.001)$. Similarly, the service quality has a positive and significant effect on the levels of satisfaction of IMFI customers at the 0.001 level of significance $(\beta=0.496, t=6.595, p<0.001)$. Therefore, these results supported the hypotheses of the study $\mathrm{H}_{1}, \mathrm{H}_{2}$, and $\mathrm{H}_{3}$ as developed in the study.

\subsection{Testing the Mediating Role of Perceived Benefits}

To test the mediating effect of the perceived benefits between service quality and satisfaction, the PLS bootstrapping algorithm was run to estimate the indirect effect among the variables. The results obtained as illustrated in Table 7 show that the service quality directly and indirectly affects significantly the satisfaction of the customers at the 0.001 level of significance with indicators $(\beta=0.751,21.308, p<0.001)$ and $(\beta=0.237, t=$ $4.417, \mathrm{p}<0.001)$ respectively. It can also be concluded that perceived benefits, as a variable, is a partial mediator between service quality and satisfaction carrying out a $32 \%$, as a Variance Accounted For (VAF), of the influence of service quality with satisfaction. This result supported the H4 that was hypothesized in the study regarding the mediating effect of the perceived benefits.

Table 7. Mediation analysis results

\begin{tabular}{|c|c|c|c|c|c|c|c|c|}
\hline \multirow{2}{*}{$\begin{array}{l}\text { Hyp. } \\
\text { No }\end{array}$} & \multirow[t]{2}{*}{ Hypothesis } & \multicolumn{3}{|c|}{ Path Coefficient } & \multirow{2}{*}{$\begin{array}{c}\text { Standard } \\
\text { Error }\end{array}$} & \multirow{2}{*}{$\begin{array}{c}T \\
\text { Value }\end{array}$} & \multirow{2}{*}{$\begin{array}{c}\mathbf{P} \\
\text { Value }\end{array}$} & \multirow[t]{2}{*}{ Decision } \\
\hline & & $\mathbf{a} * \mathbf{b}$ & c & $\mathbf{c}^{\prime}$ & & & & \\
\hline $\mathrm{H}_{4}$ & $\begin{array}{l}\text { Perceived } \\
\text { mediates } \\
\text { relationship between } \\
\text { the service quality } \\
\text { and satisfaction }\end{array}$ & $0.237 * * *$ & $0.751 * * *$ & $0.496 * * *$ & 0.054 & 4.417 & 0.000 & $\begin{array}{c}\text { Partial } \\
\text { Mediation }\end{array}$ \\
\hline
\end{tabular}

\subsection{Testing the Moderating Effect of Perceived Benefits}

In testing the moderating effect of the perceived benefits on the relationship between the service quality and satisfaction, the interaction variable was examined. The results in Table 8 showed that the moderating effect was not supported as the interaction variable introduced was insignificant $(\beta=0.43, t=0.487, p>0.05)$. The results show that the $\mathrm{H}_{5}$ regarding the moderating effect of perceived benefits on the service quality and satisfaction relationship was not supported.

Table 8. Moderating effect results

\begin{tabular}{llccccc}
\hline $\begin{array}{l}\text { Hyp. } \\
\text { No }\end{array}$ & Hypothesis & $\begin{array}{c}\text { Path } \\
\text { Coefficient }\end{array}$ & $\begin{array}{c}\text { Standard } \\
\text { Error }\end{array}$ & $\begin{array}{c}\text { T } \\
\text { Value }\end{array}$ & $\begin{array}{c}\text { P } \\
\text { Value }\end{array}$ & Decision \\
\hline $\mathrm{H}_{5}$ & $\begin{array}{l}\text { Perceived Benefits } \\
\text { relationship between service quality } \\
\text { and satisfaction }\end{array}$ & 0.04295 & 0.08821 & 0.4869 & 0.3132 & $\begin{array}{c}\text { Not } \\
\text { Supported }\end{array}$ \\
\hline
\end{tabular}




\section{Discussion and Conclusions}

The main objective of this study was to examine the effect of service quality of Islamic Microfinance system in Yemen on the satisfaction of SMEs' owners. The results of this study confirmed the effect of service quality on the level of satisfaction and perceived benefits. These results, an expected supported the hypothesis of the study by confirming the importance of service quality to keep the customers satisfied and to have a high level of perceived benefits.

Additionally, the statistical results confirmed the positive mediation of the perceived benefits between the service quality and satisfaction. This implies that high level of quality of service can affect directly the satisfaction of the clients as well as indirectly through enhancing the level of perceived benefits. On the other hand, the perceived benefits variable has no moderating effect on the relationship between service quality and satisfaction. One explanation of this result is that the benefits of dealing with Islamic Microfinance are not highly perceived and recognized. However, the perceived benefits, as a variable, were found to be a determinant of customers' satisfaction.

Future research could be of a great value if some other factors are to be included to determine the SMEs owners' satisfaction. For example, the business development services and the repayment policies could be critical factors affecting the level of customer satisfaction. In addition, the size of the business could be an influential factor of the satisfaction since small businesses' needs of consultations are different from those of bigger businesses.

The findings of this study might be of a great value to academics and Islamic bankers as well as. As an implication, for Islamic Microfinance system to be able to compete, prosper and survive, the customers should be the main focus on partners and their inputs to achieve continues service improvement should highly incorporate.

\section{References}

Al-Kuhali, M. (2012). SMEs in Yemen. Retrieved March 1, 2012, from http://www.yemeneconomist.com

Al-Marri, K., Ahmed, A. M. M. B., \& Zairi, M. (2007). Excellence in service: an empirical study of the UAE banking sector. International Journal of Quality \& Reliability Management, 24(2), 164-176. http://dx.doi.org/10.1108/02656710710722275

Al-Swidi, A. K., \& Mahmood, R. (2011). Yemeni Banking System: Critical Issues and Future Recommended Strategies. European Journal of Social Sciences, 20(4), 637-655.

Al-Tamimi, H. A. H., \& Al-Amiri, A. (2003). Analysing service quality in the UAE Islamic banks. Journal of Financial Services Marketing, 8(2), 119-132. http://dx.doi.org/10.1057/palgrave.fsm.4770112

Angelova, B., \& Zekiri, J. (2011). Measuring Customer Satisfaction with Service Quality Using American Customer Satisfaction Model (ACSI Model). International Journal of Academic Research in Business and Social Sciences, 1(3), 232-259. http://dx.doi.org/10.6007/ijarbss.v1i2.35

Angur et al. (1999). Service quality in the banking industry: an assessment in a developing economy. International Journal of Bank Marketing, 17(3), 116-125. http://dx.doi.org/10.1108/02652329910269211

Aris, N. M. (2007). SMEs: Building Blocks for Economic Growth. Department of Statistics Malaysia.

Asubonteng et al. (1996). SERVQUAL revisited: a critical review of service quality. Journal of Services Marketing, 10(6), 62-81. http://dx.doi.org/10.1108/08876049610148602

Avkiran, N. K. (1994). Developing an Instrument to Measure Customer Service Quality in Branch Banking. International Journal of Bank Marketing, 12(6), 10-18. http://dx.doi.org/10.1108/02652329410063223

Bagozzi, R. P., Yi, Y., \& Phillips, L. W. (1991). Assessing construct validity in organizational research. Administrative Science Quarterly, 36(3), 421-458. http://dx.doi.org/10.2307/2393203

Bhattacherjee, A. (2001). Understanding information systems continuance: an expectation-confirmation model. MIS Q., 25(3), 351-370. http://dx.doi.org/10.2307/3250921

Bo, Z. (2010). Research on SMEs' Transformation and Upgrading Strategies. IEEE, School of Management, Beijing Union University, Beijing.

Brandsma, J., \& Burjorjee, D. (2004). Microfinance in the Arab States Building inclusive financial sectors. United Nations Capital Development Fund.

Chin, W. W. (1998). The partial least squares approach to structural equation modeling. In G. A. Marcoulides (Ed.), Modern methods for business research (pp. 295-336). Mahwah: Lawrence Erlbaum. 
Cohen, J. (1988). Statistical power analysis for the behavioral sciences (2nd ed.). Hillsdale, Lawrence Erlbaum Associates, NJ.

Compeau, D. R., Higgins, C. A., \& Huff, S. (1999). Social Cognitive Theory and individual Reactions to Computing Technology - A Longitudinal-Study. MIS Quarterly, 23(2), 145-158. http://dx.doi.org/10.2307/249749

Consultative Group to Assist the Poor. (2011). The Challenge for Islamic Microfinance. Retrieved February 11, 2012, from http://www.cgap.org/p/site/c/template.rc/1.26.15722

Consultative Group to Assist the Poor. (2012a). Who Are the Clients of Microfinance? Retrieved from http://www.cgap.org/p/site/c/template.rc/1.26.1304/

Consultative Group to Assist the Poor. (2012b). Why Islamic microfinance not grow up until now? Retrieved February 9, 2012, from http://arabic.microfinancegateway.org/content/article/detail/60285

Cui et al. (2003). Service quality measurement in the banking sector in South Korea. International Journal of Bank Marketing, 21(4), 191-201. http://dx.doi.org/10.1108/02652320310479187

Deng et al. (2009). Understanding customer satisfaction and loyalty: An empirical study of mobile instant messages in China. International Journal of Information Management, 30(4), 289-300. http://dx.doi.org/10.1016/j.ijinfomgt.2009.10.001

Fornell, C., \& Larcker, D. F. (1981). Evaluating structural equation models with unobservable variables and measurement error. Journal of Market Research, 18(1), 39-50. http://dx.doi.org/10.2307/3151312

Fornell, C., \& Cha, J. (1994). Partial least squares. In R. P. Bagozzi (Ed.), Advanced methods of marketing research (pp. 52-78). Cambridge: Blackwell.

Ghoneim, A. F. (2002). Intellectual Property in Arab Countries. A World Intellectual Property Organization (WIPO) Forum held in Moscow, 23-25 May 2002. Moscow, Center for International Private Enterprise.

Gronroos, C. (1988). Service Quality: The Six Criteria Of Good Perceived Service. Review of Business, 9(3), $10-13$.

Gustafsson, A., Johnson, D. M., \& Roos, I. (2005). The Effects of Customer Satisfaction, Relationship Commitment Dimensions, and Triggers on Customer Retention. Journal of Marketing, 69(4), 210-218. http://dx.doi.org/10.1509/jmkg.2005.69.4.210

Hair, J. F., Anderson, R. E., Tatham, R. L., \& Black, W. C. (2010). Multivariate Data Analysis (7th ed.). Prentice Hall: USA.

Hashi, I., \& Krasniqi, B. A. (2011). Entrepreneurship and SME growth: evidence from advanced and laggard transition economies. International Journal of Entrepreneurial Behavior \& Research, 7(5), 456-487. http://dx.doi.org/10.1108/13552551111158817

Heaney, J. G., \& Goldsmith, R. E. (1999). External information search for banking services. International Journal of Bank Marketing, 17(7), 305-323. http://dx.doi.org/10.1108/02652329910305670

Hennig, T., \& Klee, A. (1997). The Impact of Customer Satisfaction and Relationship Quality on Customer Retention: A Critical Reassessment and Model Development. Psychology \& Marketing, 14(8), 737-764. http://dx.doi.org/10.1002/(SICI)1520-6793(199712)14:8<737::AID-MAR2>3.0.CO;2-F

Hussien, A. (2010). The Role of Small and Medium Enterprises in Job Creation in the Arab Countries (Arabic). Retrieved April 24, 2010 from http://ssrn.com/abstract=1595349

International Finance Corporation (IFC). (2006). A diagnostic study on Access to Finance for women entrepreneurs. Retrieved November 20, 2010, from http://www.ifc.org

Jabnoun, N., \& Al-Tamimi, H. A. H. (2003). Measuring perceived service quality at UAE commercial banks. International Journal of Quality \& Reliability Management, 20(4), 458-472. http://dx.doi.org/10.1108/02656710310468614

Jalilian, H., \& Kirkpatrick, C. (2001). Financial development and poverty reduction in developing countries. Working Paper No. 30, Institute for Development Policy and Management, University of Manchester.

Jasra, J. M., Khan, M. A., Hunjra, A. I., Rehman, R. A. U., \& Azam, R. I. (2011). Determinants of Business Success of Small and Medium Enterprises. International Journal of Business and Social Science, 2(20), 274-280. 
Jun, M., \& Cai, S. (2001). The key determinants of Internet banking service quality: a content analysis. International Journal of Bank Marketing, 19(7), 276-291. http://dx.doi.org/10.1108/02652320110409825

Khalid, S., Mahmood, B., Abbas, M., \& Hussain, S. (2011). Customer Satisfaction with Service Quality in Conventional Banking in Pakistan: The Case of Faisalabad. International Journal of Marketing Studies, 3(4), 165-174. http://dx.doi.org/10.5539/ijms.v3n4p165

Kim, H. D., LaVetter, D., Lee, J. H., \& Jayachandra, B. (2006). The Influence of Service Quality Factors on Customer Satisfaction and Repurchase Intention in the Korean Professional Basketbal 1 League. International Journal of Applied Sports Sciences, 18(1), 39-58.

Lam, T. P. (2002). Making Sense of SERVQUAL's Dimensions to the Chinese Customers in Macau. Journal of Market-Focused Management, 5(1), 43-58. http://dx.doi.org/10.1023/A:1012575412058

Madill, J. J., Feeney, L., Riding, A., \& Haines Jr, G. H. (2002). Determinants of SME owners' satisfaction with their banking relationships: a Canadian study. International Journal of Bank Marketing, 20(2), 86-98. http://dx.doi.org/10.1108/02652320210419698

Malhotra, M., Chen, Y., Criscuolo, A., Fan, Q., Hamel, I. I., \& Savchenko, Y. (2006). Expanding Access to Finance: Good Practices and Policies for Micro, Small, and Medium Enterprises Washington, World Bank Institute.

Ministry of Planning and International Cooperation (MOPIC). (2004). Policies and programs of development for small and medium enterprises in the Republic of Yemen. Retrieved from http://www.mpicyemen.org/2006/nhdr/arabic/nhdr_rp/nhdr/nhdr4.pdf

National Information System - Yemen. (2012). Main Industry Indicators for (2000-2004). Retrieved October 8, 2011, from http://www.yemen-nic.net/contents/Idustrial/section.php?\&SECTION_ID=160\&PHPSESSID=ae53c894ecc 12c59b1672a943789064c

National SME Development Council. (2011). SME annual report 2009/10. Kuala Lumpur.

Navajas, S., Schreiner, M., Meyer, R. L., Gonzalez-Vega, C., \& Rodriguez-Meza, J. (2000). Microcredit and the Poorest of the Poor: Theory and Evidence from Bolivia. World development, 28(2), 333-346.

Newman, K. (2001). Interrogating SERVQUAL: a critical assessment of service quality measurement in a high street retail bank. International Journal of Bank Marketing, 19(3), 126-139. http://dx.doi.org/10.1108/02652320110388559

Oliver, R. (1997). Satisfaction: A behavioral perspective on the consumer. Boston: Irwin McGraw-Hill.

Osman, I., Ali, H., Zainuddin, A., Rashid, W. E. W., \& Jusoff, K. (2009). Customers Satisfaction in Malaysian Islamic Banking. International Journal of Economics and Finance, 1(1), 197-202.

Othman, A., \& Owen, L. (2001). Adopting and Measuring Customer Service Quality (Sq) in Islamic Banks: A Case Study in Kuwait Finance House. International Journal of Islamic Financial Services, 3(1), 1-26.

Parasuraman, A., Berry, L. L., \& Zeithaml, V. A. (1991). Refinement and Reassessment of the SERVQUAL Scale. Journal of Retailing, 67(4), 420-450.

Parasuraman, A., Zeithaml, A., \& Berry, L. (1994). Reassessment of expectations as a comparison standard in measuring service quality: implications for further research. The Journal of Marketing, 58(1), 111-124. http://dx.doi.org/10.2307/1252255

Parasuraman, A., Zeithaml, V. A., \& Berry, L. L. (1988). Servqual. Journal of Retailing, 64(1), 12-37.

Parasuraman, A., Zeithaml, V., \& Berry, L. (1985). A conceptual model of service quality and its implications for future research. The Journal of Marketing, 49(4), 41-50. http://dx.doi.org/10.2307/1251430

Punj, G. N., \& Staelin, R. (1983). A model of consumer information search behavior for new automobiles. Journal of Consumer Research, 9(4), 366-380. http://dx.doi.org/10.1086/208931

Rahman, A. R. A. (2007). Islamic Microfinance: A Missing Component in Islamic Banking. Kyoto Bulletin of Islamic Area Studies, 1(2), 38-53.

Ramdhani et al. (2011). The Influence of Service Quality toward Customer Satisfaction of Islamic Sharia Bank. Australian Journal of Basic and Applied Sciences, 5(9), 1099-1104. 
Richard, \& Oliver (1999). Whence Consumer Loyalty. The Journal of Marketing Fundamental Issues and Directions for Marketing, 63(special issue), 33-44.

Schmidt, J. B., \& Spreng, R. A. (1996). A proposed model of external consumer information search. Journal of the academy of Marketing Science, 24(3), 246-256. http://dx.doi.org/10.1177/0092070396243005

Shafie, S., Azmi, W. N. W., \& Haron, S. (2004). Adopting and Measuring Customer Service Quality in Islamic Banks: A Case Study of Bank Islam Malaysia Berhad. Journal of Muamalat and Islamic Finance Research, 1(1), 1-12.

Srinivasan, N., \& Ratchford, B. T. (1991). An empirical test of a model of external search for automobiles. Journal of Consumer Research, 18(2), 233-242. http://dx.doi.org/10.1086/209255

Sureshchandar, G. S., Rajendran, C., \& Anantharaman, R. N. (2003). Customer perceptions of service qality in the banking sector of a developing economy: a critical analysis. International Journal of Bank Marketing, 21(5), 233-242. http://dx.doi.org/10.1108/02652320310488411

Tahir, I. M., \& Bakar, N. M. A. (2007). Service Quality Gap and Customers' Satisfactions of Commercial Banks in Malaysia. International Review of Business Research Papers, 3(4), 327-336.

Tenenhaus, M., Esposito Vinzi, V., Chatelin,Y. M., \& Lauro, C.(2005). PLS path modeling. Computational Statistics \& Data Analysis, 48(1), 159-205. http://dx.doi.org/10.1016/j.csda.2004.03.005

Tse, K. D., \& Wilton, C. P. (1988). Models of consumer satisfaction formation: An extension. Journal of Marketing Research, 25(2), 204-212. http://dx.doi.org/10.2307/3172652

Turel, O., \& Serenko, A. (2006). Satisfaction with mobile services in Canada: An empirical investigation. Telecommunications Policy, 30(5-6), 314-331. http://dx.doi.org/10.1016/j.telpol.2005.10.003

Vibha, A., \& Nravichandran, N. K. J. (2011). Dimensionality of Service Quality and Its Critical Predictors to Customer Satisfaction in Indian Retail Banking. International Journal of Multidisciplinary Research, 1(5), $1-11$.

Wetzels, M., Odekerken-Schröder, G., \& Oppen, C. V. (2009). Using PLS path modeling for assessing hierarchical models: Guidelines and empirical illustration. MIS Quarterly, 33(1), 177-195.

Yemen country profile. (2008). Country Profile - Yemen. Retrieved February 12, 2012, from http://www.unhcr.org/refworld/publisher,USLC,,4950afd20,0.html

\section{Copyrights}

Copyright for this article is retained by the author(s), with first publication rights granted to the journal.

This is an open-access article distributed under the terms and conditions of the Creative Commons Attribution license (http://creativecommons.org/licenses/by/3.0/). 